\title{
Introduction to Economic History
}

\section{University of World and National Economy, Sofia, Bulgaria}

\section{ANNOTATION}

\section{Background of the discipline.}

Prerequisites: no

\section{Description of the course content:}

The course presents an overview of world economic history with a special focus on the causes of economic development of Europe, and the economic forces shaping social institutions in various periods. Much of the course will be devoted to characterizing and explaining the onset of modern economic growth, associated with the industrial Revolution and its consequences. This course provides also an introduction to the history of the international economy over the past two centuries. Topics include the rise of the Western world, the Industrial revolution, the rise and the fall of the great economic powers in $19-20^{\text {th }}$ centuries (UK, USA, Germany, Russia, China, Japan), the world economy since 1945. Students will gain an economic understanding of the development of the modern capitalism.

The course assumes no prior student backgrounds in either history or economics. All it asks of students is an active interest in developing their intellectual skills and in learning about the broad historical trends that influence their lives.

\section{The course is taught in English.}

\section{CURRICULUM CONTENTS}

\section{LECTURES}

\begin{tabular}{|c|l|c|c|}
\hline № & TOPICS & $\begin{array}{c}\text { Student's } \\
\text { academic } \\
\text { commitm } \\
\text { ents } \\
\text { (number } \\
\text { of hours). }\end{array}$ & $\begin{array}{c}\text { Student's } \\
\text { out-class } \\
\text { academic } \\
\text { commitm } \\
\text { ents } \\
\text { (number } \\
\text { of hours). }\end{array}$ \\
\hline Section 1 & \begin{tabular}{c} 
\\
\hline 1.
\end{tabular} & $\begin{array}{l}\text { Introduction: Economic History - definition; why study } \\
\text { Economic history? Periodization in world history. }\end{array}$ & \\
\hline 2. & The Rise of the Western world: economic development & 5 & \\
\hline
\end{tabular}




\begin{tabular}{|c|c|c|c|}
\hline & $\begin{array}{l}\text { in Medieval Europe; feudal system and long-distance } \\
\text { trade; the crisis of the Medieval economy; commercial } \\
\text { currents and techniques; the age of discoveries and } \\
\text { the rise of the West; the scientific revolution }\end{array}$ & & \\
\hline \multicolumn{4}{|c|}{ Section 2} \\
\hline 3. & $\begin{array}{l}\text { The Industrial Revolution: prerequisites; agricultural } \\
\text { revolution: characteristics of Modern industry; industrial } \\
\text { technology and innovation; regional variation; social } \\
\text { aspects of industrialization. }\end{array}$ & 5 & \\
\hline 4. & $\begin{array}{l}\text { British economy during the } 19^{\text {th }} \text { and early } 20^{\text {th }} \text { century: } \\
\text { the basic economic determinants; industrialization, } \\
\text { railways, trade and transformation, financial sector; the } \\
\text { relative decline of Britain at the end of } 19^{\text {th }} \text { century. }\end{array}$ & 3 & \\
\hline 5. & $\begin{array}{l}\text { The economy of the USA 1783-1914: agriculture, } \\
\text { slavery and westward expansion; industry, } \\
\text { transportation and financial system. }\end{array}$ & 3 & \\
\hline 6. & $\begin{array}{l}\text { The German economy during the } 19^{\text {th }} \text { and early } 20^{\text {th }} \\
\text { century: the foundations of economic growth, } \\
\text { Zollverein and early industrialization; national } \\
\text { unification and its economic consequences; } \\
\text { industrialization and monopolization; colonial fights. }\end{array}$ & 3 & \\
\hline 7. & $\begin{array}{l}\text { Economy of Russia from the Industrial revolution to the } \\
\text { revolution of 1917: the Industrial Revolution in Russia } \\
\text { and the abolition of serfom; foreign investments and } \\
\text { industrialization; economic reforms and social tensions. }\end{array}$ & 3 & \\
\hline 8. & $\begin{array}{l}\text { The Bulgarian economy 1878-1944: the new } \\
\text { institutions and the economy; agriculture, industry, } \\
\text { trade and financial system; the wars and its economic } \\
\text { impact; the main economic trands during the interwar } \\
\text { period. }\end{array}$ & 3 & \\
\hline 8. & $\begin{array}{l}\text { World economy during the interwar period: the } \\
\text { economic consequences of the First world war; the } \\
\text { great Depression and the rival attempts at } \\
\text { reconstruction. }\end{array}$ & 6 & 12 \\
\hline \multicolumn{4}{|c|}{ Section 3} \\
\hline 9. & $\begin{array}{l}\text { Japanese economy at the end of } 19^{\text {th }} \text { and in } 20^{\text {th }} \\
\text { century: Isolationism and Meiji restoration; agriculture } \\
\text { and industrialization; the effects of the WWI on } \\
\text { Japanese economy; Japanese economy between the } \\
\text { world wars; the Japanese post WWII economic } \\
\text { miracle; the Japanese economy at the end of } 20^{\text {th }} \\
\text { century }\end{array}$ & 3 & \\
\hline 10. & $\begin{array}{l}\text { Economic development of China in } 20^{\text {th }} \text { century: } \\
\text { isolationism and foreign dependence; the revolution of } \\
1911-1912 \text {; civil war and economic reforms of } \\
\text { Kuominang; economic devastation; the reforms of the } \\
\text { Chinese Communist Party; the Great Leap formard } \\
\text { and the Great Famine; Cultural revolution; market - } \\
\text { oriented reforms. }\end{array}$ & 5 & \\
\hline 11. & $\begin{array}{l}\text { Western European Economy since 1945: Economic } \\
\text { consequences of the Second World War; Recovery; } \\
\text { The Golden Age 1950-1973; the end of the } 20^{\text {th }}\end{array}$ & 5 & \\
\hline
\end{tabular}




\begin{tabular}{|c|c|c|}
\hline & century & \\
\hline 12. & $\begin{array}{l}\text { The Economy of the USA since 1945: The WWII and } \\
\text { its economic compact; the Golden age - 1950s and } \\
1960 \text { s; Inflation and oil shocks; Reaganomics and } \\
\text { prosperity of 1990s. }\end{array}$ & 5 \\
\hline 13. & $\begin{array}{l}\text { Economy of USSR and its Impact on Eastern Europe } \\
\text { since 1945: Economy of USSR } 1917-1953 \text {; Post-war } \\
\text { Eastern Europe and USSR; the Bulgarina economy } \\
\text { 1944-1989; the demise of the Soviet system. }\end{array}$ & 5 \\
\hline 14. & $\begin{array}{l}\text { The Economy of Latin America and Africa since 1945: } \\
\text { A) Latin America - The WWII and its economic } \\
\text { aftermath; the Latin American economies } \\
\text { 1950s-1980s; Crisis and reforms. } \\
\text { B) Africa - The WWII and its economic aftermath; } \\
\text { the decolonization and its consequences; post- } \\
\text { colonial economy. }\end{array}$ & 5 \\
\hline
\end{tabular}

Mark: Each topic gives the opportunity for defining of a practical task, which is executed as an individual experimental work

\section{METHOD / TEACHING STRATEGY:}

The teaching is done through a combination of lectures and discussions. To illustrate the teaching are used slides, print and online sources of information.

\section{EVALUATION METHOD}

\begin{tabular}{|c|c|c|c|c|c|c|}
\hline Excellent $/ 6 / /$ & Very good $/ 5 /$ & Good $/ 4 /$ & \multicolumn{2}{|c|}{ Fair $/ 3 /$} & Poor $/ 2 /$ \\
\hline A & B & C & D & E & FX & F \\
\hline $80 \%$ & $\begin{array}{c}75 \% \\
70 \%\end{array}$ & $60 \%$ & \multicolumn{2}{c|}{$\begin{array}{c}\text { No credits awarded } \\
50 \%\end{array}$} \\
\hline
\end{tabular}

The degree of students' knowledge on the discipline "Introduction to Economic History" is determined on the basis of a complex final mark. The final mark is formed from the current mark from the semester and the mark from the final test exam. The current mark is formed as follows:

- Presence on the lectures and participation $-10 \%$;

- Midterm test-30\%;

- Final test $-60 \%$.

\section{EXPECTED RESULTS FROM THE COURSE}

Training course on "Introduction to Economic History" provides well-balanced set of scientific knowledge in the field of:

- methodological bases and methodical principles for the study of economy;

- general laws of the market mechanism and the peculiarities of the functioning of specific national and regional markets;

- conjuncture-formation variety of factors that determine the current status, trends and prospects in world economy; 
- formation of "knowledge" about the historical development and structure of the world economy.

In the process of teaching the course "International Market Studies" students acquire the following skills:

- to enhance the ability to do independent research by developing the student's ability to locate and critically evaluate the sources of information;

- to develop the student's ability to apply economic theory and economic way of thinking to real world events;

- to distinguish the main factors of economic growth: their characteristics and mechanism of influence of each on a specific national and international market;

- to use different methodologies for analyzing of main economic trends.

\section{BIBLIOGRAPHY}

A. BASIC

1. Penchev, Pencho, Lectures on Modern Economic History, 2011.

2. Cameron, R., L. Neal, A Concise Economic History of the World, Oxford University Press, 2003.

3. Persson, Karl, Gunnar, An Economic History of Europe, Cambridge University Press, 2010.

4. Heilbroner, Robert, The Making of Economic Society, Pearson Prentice Hall, 2008.

5. Aldcroft, Derek, The European Economy 1914-1990, Routledge, 1993.

6. Berend, Ivan, An Economic History of Twentieth-Century Europe, Campbridge University Press, 2006.

7. The Cambridge Economic History of Modern Europe, volume 2: 1870 to the Present. Edited by Stephen Broadberry and Kevin H. O'Rourke, Cambridge University Press, 2010.

8. Hughes, Jonathan, Louis P. Cain, American Economic History, Seventh Edition, Pearson Education, 2007.

9. Maddison, Angus, Contours of the World Economy 1-2030 AD. Essays in MacroEconomic History, Oxford University Press, 2007.

10. The Oxford Encyclopedia of Economic History, Oxford University Press, 2003

11. Landes, David, The Wealth and Poverty of Nations, New York, London, 1999

12. North, D, Robert Paul Thomas, The Rise of the Western World, A New Economic History, Cambridge University Press, 1980

13. van Zanden, Jan Luiten, The Long Road to the Industrial Revolution, Leiden, Boston, 2009.

14. Cipolla, Carlo, Before the Industrial Revolution, European Society and Economy 1000-1700, New York, London, 1994

15. Cipolla, Carlo, Between two Cultures, An Introduction to Economic History, New York, London, 1992.

16. Polanyi, Karl, The Great transformation, The Political and economic Origins of our Time, Beacon Press, 2001.

17. Allen, Robert, The British Industrial Revolution in Global Perspective, Cambridge University press, 2009

B. ADDITIONAL

1. Allen, Robert, Farm to Factory: A Reinterpretation of the Soviet Industrial Revolution, Princeton and Oxford: Princeton University Press 2003. 
2. Eichengreen, Barry, The European Economy since 1945, Princeton University Press, 2007.

3. Kornai Janos, The Socialist System. Political Economy of Communism, Oxford University Press, 1992.

4. Nove, Alec, An Economic History of USSR, Penguin Books, 1976.

5. Stearns, Peter, Globalization in World History, Routledge, 2010.

6. Johnson, Paul, A History of the American People, Harper Collins Publishers, 1997.

7. Seavoy, E. Ronald, An Economic History of the United States From 1607 to the Present, Routledge, 2006.

8. Eichengreen, Barry, Exorbitant Privilege, The Rise and Fall of the Dollar, Oxford University Press, 2011.

9. Sutcliffe, Anthony, An Economic and Social History of Western Europe since 1945, Longman, 1996.

10. Origins and Evolution of the European Union. Edited by Desmond Dinan, Oxford University Press, 2006.

11. Beattie, Alan, False Economy. A Surprising Economic History of the World, Penguin Books, 2010.

12. Cooper, Frederic, Africa since 1940. The Past of the Present. New Approaches to African History, Cambridge University Press, 2002.

13. The Cambridge History of Latin America, Volume VI, Latin America since 1930, Economy, Society and Politics, Part I, Economy and Society, Cambridge University Press 1994.

14. The British Industrial Revolution, An Economic Perspective, edited by Joel Mokyr, Westview Press, 1999.

15. Kenwood, A., G., A. L.ougheed, The Growth of the International Economy 18202000, Routledge, 2006.

16. O'Grada, Cormac, Famine, A Short History, Princeton University Press, 2009.

17. Federico, Giovanni, Feeding the World, An Economic History of Agriculture 18002000, Princeton University Press, 2005

18. Pomeranz, Kenneth, The Great Divergence, China Europe and the Making of the Modern World Economy, Princeton University Press, 2000.

19. Clark, Gregory, A Farewell to Alms, A Brief Economic History of the World, Princeton University Press, 2007.

20. Findlay, R., Kevin O'Rourke, Power and Plenty, Trade, War and the World Economy in the Second Milenium, Princeton University Press, 2007.

21. Bernstein, William, A Splendid Exchange, How Trade Shaped the World, Atlantic Books, 2008.

22. Ferguson, N., The Cash Nexus, Money and the Power in the Modern World 17002000, Basic Books, 2001.

23. Chandler, Alfred, Scale and Scope, The Dynamics of industrial Capitalism, The Belknap Press of Harvard University Press, 2004.

24. Galbraith, John Kenneth, The Great Crash, Penguin Books, 2009.

25. Hobsbawm, Eric, Industry and Empire, Penguin Books, 1999.

26. Hobsbawm, Eric, The Age of Capital 1848-1875. Abacus 2008.

27.van Zanden, Jan L., The Economic History of the Netherlands, A Small Open Economy in the Long Twentieth Century, Routledge, 1997.

28. Mommen, Andre, The Belgian Economy in the Twentieth Century, Routledge, 1999.

29. Gershencron, A., Economic Backwardness in Historical Perspective, The Belknap Press of Harvard University Press, 1962.

30. van der Wee, Herman, Prosperity and Upheaval, The World Economy 1945-1980, Viking, 1986. 


\section{PREPARED BY:}

Associate Professor Pencho D. Penchev, PhD 